\title{
NITROGEN REMOVAL FROM MUNICIPAL WASTEWATER USING INTEGRATED FIXED FILM ACTIVATED SLUDGE PROCESS AND ANOXIC PROCESS
}

\author{
Nway Nway Khaing ${ }^{1}$, Theingi Ye Myint ${ }^{2}$, and Cho Cho Thin Kyi ${ }^{3}$ \\ ${ }^{1}$ Civil Engineering Department, Yangon Technological University, \\ Insein Township, Yangon, Myanmar, Tel: +959254253675, e-mail: nnkhaing2@gmail.com \\ ${ }^{2}$ Civil Engineering Department, Yangon Technological University, \\ Insein Township, Yangon, Myanmar, Tel: +9595095555, e-mail: tgym559@gmail.com \\ ${ }^{3}$ Civil Engineering Department, Yangon Technological University, \\ Insein Township, Yangon, Myanmar, Tel: +9595185438, e-mail: ccthinkyi@gmail.com
}

Received Date: October 19, 2018; Revised Date: May 9, 2019; Acceptance Date: July 15, 2019

\begin{abstract}
This research was carried out using lab-scaled Integrated Fixed Film Activated Sludge (IFAS) process with fabious media and anoxic process in order to reduce the concentration of ammonia nitrogen and nitrate nitrogen in municipal wastewater from Yangon City, Myanmar. The required wastewater sample was collected from the wastewater treatment plant of Yangon City Development Committee (YCDC). Ten experiments were conducted with five operational conditions and they lasted about four months from February to May 2018. The rate of air supply for the aeration tank through these experiments was about $8 \mathrm{~m}^{3} /$ day. This paper describes the evaluation on nitrogen removal efficiency of the lab-scaled treatment system depending on the results from the experiments. Due to the different operational conditions through these experiments, the F/M ratio of IFAS process varied between 0.1 and $0.9 \mathrm{~d}^{-1}$ and SRT of IFAS process ranged between 6.0 days and 8.3 days. Moreover, the F/M ratio fluctuated between $0.2 \mathrm{~d}^{-1}$ and $0.7 \mathrm{~d}^{-1}$ as well as the Specific Rate of Denitrification (SRDN) altered between $0.23 \mathrm{~g} \mathrm{NO}_{3}-\mathrm{N} / \mathrm{g}$ MLSS and $0.33 \mathrm{~g} \mathrm{NO}_{3}-\mathrm{N} / \mathrm{g}$ MLSS in the anoxic process. According to the outcomes of the experiments, the maximum removal efficiency for ammonia nitrogen and nitrate nitrogen were about $98.2 \%$ and $97.7 \%$, respectively. However, the optimum treatment efficiency for both $\mathrm{NH}_{3}-\mathrm{N}$ and $\mathrm{NO}_{3}-\mathrm{N}$ concentration was obtained at the ninth experiment with about $0.1 \mathrm{~d}^{-1}$ of the $\mathrm{F} / \mathrm{M}$ ratio and about 6.4 days of SRT in aerobic reactor while the F/M ratio, SRDN and anoxic residence time of anoxic process were about $0.26 \mathrm{~d}^{-1}, 0.27 \mathrm{~g} \mathrm{NO}_{3}-\mathrm{N} / \mathrm{g}$ MLSS and 48 hours, respectively. About $500 \mathrm{mg} / \mathrm{l}$ of ammonia nitrogen can be reduced to about $30 \mathrm{mg} / \mathrm{l}$ and about $2600 \mathrm{mg} / \mathrm{l}$ of nitrate nitrogen can be reduced to about $61 \mathrm{mg} / \mathrm{l}$, respectively in this ninth experiment. The optimum treatment efficiency for ammonia nitrogen and nitrate nitrogen were about $94.0 \%$ and $98.0 \%$, respectively.
\end{abstract}

Keywords: Ammonia nitrogen, Anoxic process, Integrated Fixed Film Activated Sludge (IFAS) process, Municipal wastewater, Nitrate nitrogen

\section{Introduction}

At the present time, the amount of municipal wastewater generated from municipalities in every region of the world is higher than that of the previous decades due to the rapid population growth rate of these areas. Since the municipal wastewater is composed of highly organic and inorganic pollutants with significant amount of grease, grit, debris, nutrients, bacteria, virus and parasite, the receiving surface water areas can be exactly 
contaminated if the untreated municipal wastewater is discharged into the surrounding water bodies. Pollution of water resources grow into one of the major issues to get good quality of water for drinking and domestic purposes. Therefore, the municipal wastewater should be treated by using the appropriate technologies before disposing it into the surrounding water bodies. Moreover, the nitrogen contamination due to the untreated municipal wastewater comes to be serious concern regarding eutrophication problem. Nitrogen compounds in wastewater motivate the growth of aquatic vegetation in the receiving waters. Significant increase of algae bloom can get worse the water quality that is essential for the ecosystem. Furthermore, this problem can cause oxygen depletion in water that is leading to the death of large amounts of aquatic lives. For that reason, the nitrogen compounds such as ammonia nitrogen and nitrate nitrogen constituents in municipal wastewater should be reduced until their concentration can meet with the national guideline values before disposing it to the inland water bodies. According to the results of laboratory tests, the average concentration of $\mathrm{BOD}, \mathrm{COD}$ and $\mathrm{NH}_{3}-\mathrm{N}$ of wastewater sample were very high and they were more than $1500 \mathrm{mg} / \mathrm{l}$, more than $8000 \mathrm{mg} / \mathrm{l}$ and more than $800 \mathrm{mg} / \mathrm{l}$, respectively. The aim of this study was to determine the optimum treatment efficiency of IFAS process with fabious media as biocarriers and anoxic process for reduction of ammonia nitrogen and nitrate nitrogen concentration in the municipal wastewater sample that is a mixture of sewage and septage from septic tanks from Yangon City. This fabious media had never been used as bio carriers in the IFAS process for the treatment of very concentrated municipal wastewater from Yangon City. In this research, ten experiments were carried out so that the optimum treatment condition can be determined with five different operational conditions by varying the amount of returned activated sludge and anoxic residence time.

\section{Collection of Wastewater Sample}

The municipal wastewater samples required for running experiments in this research were collected from the influent tank of the Wastewater Treatment Plant (WWTP) of Yangon City Development Committee (YCDC). The samples were collected twice a month from March 2018 to May 2018. Experiments were carried out by constructing lab-scaled physical model at the Environmental Engineering laboratory of Yangon Technological University (YTU).

\section{Set-Up of Lab-Scaled Treatment System}

The lab-scaled treatment system of this research consisted of two components. The first component is the lab-scaled IFAS process and second one is the lab-scaled anoxic process.

The lab-scaled IFAS process was composed of one aeration tank with bio-carriers known as fabious media and one sedimentation tank. The IFAS process is a process by combining the fixed-film and the suspended activated sludge processes. The addition of fabious media to the aeration basin can help to achieve better nitrifying efficiency by obtaining the larger surface area for the attachment and growth of microbes and necessary sludge volume without requiring larger volume of aeration tank than conventional activated sludge process. The fabious media is made of polyester polypropylene with about $83 \%$ of porosity and each piece has cylinder with gear cross section. The diameter and thickness of each piece are $8 \mathrm{~mm}$ and $8 \mathrm{~mm}$, respectively. About $0.002 \mathrm{~m}^{3}$ of bio-carriers named fabious were added in a $0.016 \mathrm{~m}^{3}$ of aeration tank. The activated sludge sample needed for acclimatization of aerobic microorganisms was collected from the WWTP of YCDC and then, the sludge sample was mixed with the influent and fabious media for one month. This aerobic reactor was made of acrylic with the length of $0.3 \mathrm{~m}$, width of $0.15 \mathrm{~m}$ 
and depth of $0.38 \mathrm{~m}$. The rate of aeration was about $0.0055 \mathrm{~m}^{3} / \mathrm{min}$. In case of the sedimentation tank, there were three parts which were inlet structure, settling tank and outlet structure. The length, width and depth of inlet structure were about $0.3 \mathrm{~m}, 0.1 \mathrm{~m}$ and $0.46 \mathrm{~m}$, respectively while the outlet structure was about $0.3 \mathrm{~m}$ long, $0.1 \mathrm{~m}$ wide and $0.3 \mathrm{~m}$ high. The settling tank was about $0.6 \mathrm{~m}$ long, $0.1 \mathrm{~m}$ wide and $0.2 \mathrm{~m}$ high. The bottom of the inlet structure and settling tank were inclined in order to dispose the sludge sediments. The bed slope angle of the inlet structure and settling tank were about $25^{\circ}$ and $10^{\circ}$, respectively.

The lab-scaled anoxic process consisted of one anoxic tank with mixing system. Although the anoxic tank is generally placed before aeration tank in most researches about the removal of nitrogen from wastewater using anoxic-oxic process, in this study, the anoxic tank was located between aeration tank and sedimentation tank so that the nitrate nitrogen concentration obtained by nitrification process in the aeration tank can be reduced in this anoxic tank by denitrification process. Since the wastewater had high concentration of ammonia nitrogen, the anoxic zone had created after aerobic zone as mentioned in Figure 1. The volume, length, width and depth of anoxic tank were about $0.018 \mathrm{~m}^{3}, 0.25 \mathrm{~m}$, $0.25 \mathrm{~m}$ and $0.36 \mathrm{~m}$, respectively. The rate of mixing system was about 100 revolutions per minute (rpm) to maintain the microbial solids in suspension without transferring oxygen to the contents.

The aeration tank, anoxic tank and the inlet structure of sedimentation tank were fed sequentially with the flow rate of $1 \mathrm{~m}^{3} /$ day. The flow rate of influent entered into the settling tank was controlled about $0.02 \mathrm{~m}^{3} / \mathrm{d}$ in order to get necessary horizontal velocity that is less than the settling velocity of the sediments in wastewater. The outlet tap of inlet structure of the sedimentation tank was adjusted to discharge the effluent from anoxic tank that was stored in the inlet structure to the sedimentation tank with the flow rate about 0.02 $\mathrm{m}^{3} / \mathrm{d}$. This flow rate cannot be controlled exactly because of the declining water level in the inlet structure. The schematic diagram of this lab-scaled treatment system is shown in the Figure 1.

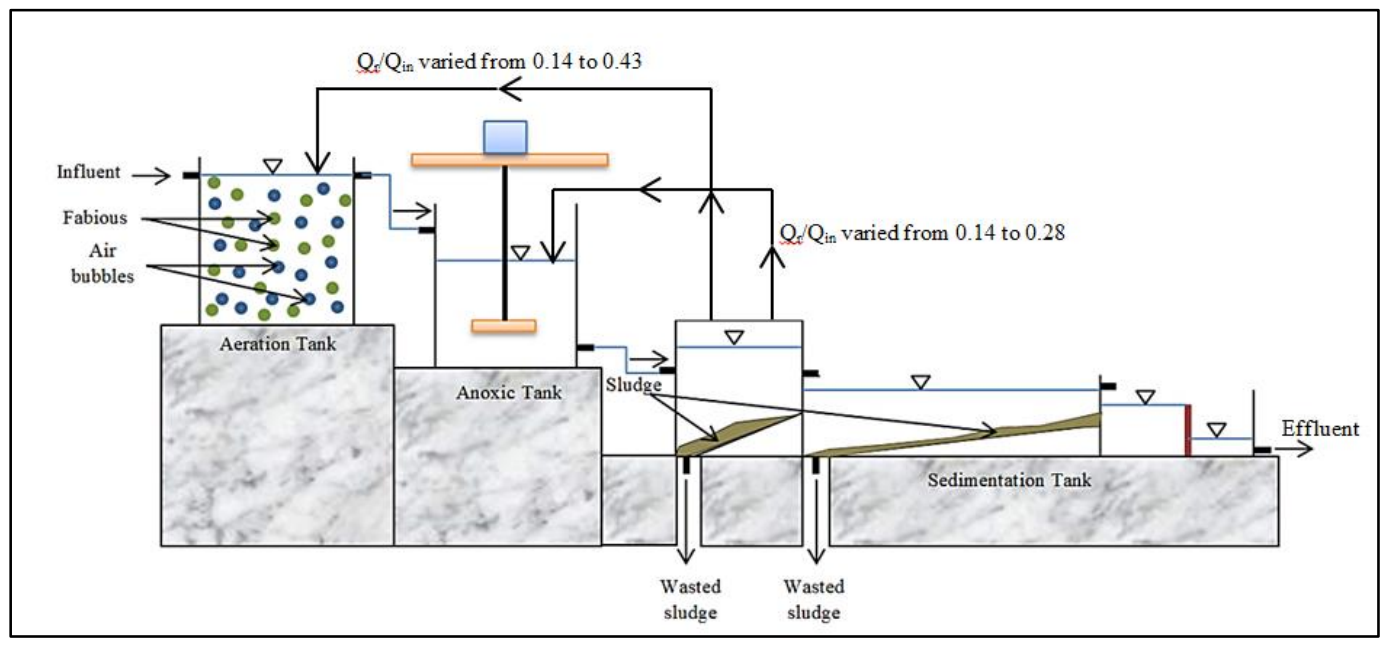

Figure 1. Schematic diagram of lab-scaled wastewater treatment system

\section{Operational Condition of Lab-Scaled Treatment System}

After one-month period of acclimatization process, the experiments were performed from March 2018 to May 2018. Lab-scaled physical models were developed and ten experiments were carried out using this developed model in Environmental Engineering 
laboratory of Yangon Technological University (YTU). The experiments were conducted continuously every day and stopped after treating about 7 Litres of wastewater per time of experiment in one day. However, the wastewater samples at every step of treatment processes could be collected and determined their quality parameters once per week due to the availability of lab facilities. About 2 to 3 Litres of Returned Activated Sludge (RAS) was recycled to the aeration tank and about 1 to 2 Litres of RAS was recycled to the anoxic tank through these ten experiments. In order to promote the removal efficiency of ammonia nitrogen and nitrate nitrogen concentration, the experiments were performed with different operating conditions by changing the amount of RAS and anoxic residence time, as described in Table 1.

Table 1. Different Operational Conditions of Lab-scaled Treatment System

\begin{tabular}{cccccccc} 
Operational & \multicolumn{3}{c}{ IFAS Process } & \multicolumn{4}{c}{ Anoxic Process } \\
\hline Condition & $\begin{array}{c}\text { Flow } \\
\text { Rate } \\
\left(\mathbf{m}^{\mathbf{3}} / \mathbf{d}\right)\end{array}$ & $\begin{array}{c}\text { Rate of } \\
\text { Oxygen } \\
\text { Supply } \\
\left(\mathbf{m}^{\mathbf{3}} / \mathbf{d a y}\right)\end{array}$ & $\mathbf{Q}_{\mathrm{r}} / \mathbf{Q}_{\text {in }}$ & $\begin{array}{c}\text { Flow } \\
\text { Rate } \\
\left(\mathbf{m}^{\mathbf{3}} / \mathbf{d}\right)\end{array}$ & $\begin{array}{c}\text { Mixing } \\
\text { System } \\
(\mathbf{r p m})\end{array}$ & $\mathbf{Q}_{\mathrm{r}} / \mathbf{Q}_{\text {in }}$ & $\begin{array}{c}\text { Anoxic } \\
\text { Residence } \\
\text { Time } \\
(\mathbf{h o u r} \mathbf{s})\end{array}$ \\
\hline 1 & 1 & 8 & 0.43 & 1 & 100 & 0 & 24 \\
2 & 1 & 8 & 0.43 & 1 & 100 & 0 & 48 \\
3 & 1 & 8 & 0.43 & 1 & 100 & 0 & 36 \\
4 & 1 & 8 & 0.28 & 1 & 100 & 0.14 & 48 \\
5 & 1 & 8 & 0.14 & 1 & 100 & 0.28 & 48 \\
\hline
\end{tabular}

In condition no. 1, 2 and 3, the anoxic residence time (ART) to keep the contact between aerobic microorganisms and nitrogen compounds in wastewater was controlled about 24 hours, 48 hours and 36 hours with about 0.43 of recirculation ratio from the sedimentation tank to the aeration tank. In condition no. 4 , the experiments were conducted with about 48 hours of ART in anoxic system with about 0.14 and 0.28 of $\mathrm{Q}_{\mathrm{r}} / \mathrm{Q}_{\text {in }}$ ratio by recycling RAS from the sedimentation tank to the anoxic tank and to the aeration tank, respectively. In condition no. 5, the experiments were performed with about 0.28 of $\mathrm{Q}_{\mathrm{r}} / \mathrm{Q}_{\text {in }}$ ratio by recycling RAS to the anoxic tank and with about 0.14 of $\mathrm{Q}_{\mathrm{r}} / \mathrm{Q}_{\text {in }}$ ratio by recycling RAS to the aeration tank. The operating conditions were changed for every two experiments. The oxygen required for aeration process was supplied with the rate of 0.33 $\mathrm{m}^{3} / \mathrm{hr}$ in terms of air at the room temperature.

The important control parameters of IFAS process such as biomass yield (Y), endogenous decay coefficient $\left(\mathrm{K}_{\mathrm{d}}\right)$, the substrate concentration at one-half of the maximum growth rate $\left(\mathrm{K}_{\mathrm{s}}\right)$ and the maximum rate of substrate utilization per unit mass of microorganisms (k) were determined based on the values of Sludge Retention Time (SRT), the ratio of food to microorganisms (F/M ratio or $\mathrm{U}$ ) and soluble $\mathrm{BOD}_{5}$ of effluent $(\mathrm{S})$ as shown in Figure 2 and Figure 3 because these coefficient values can vary as a function of the wastewater source, microbial population and temperature. The biomass yield is the ratio of the amount of biomass produced to the amount of substrate consumed. In this research, since the municipal wastewater contained a large amount of organic compounds, the yield was based on a measurable parameter reflecting the overall organic compound consumption such as BOD. The endogenous decay coefficient describes the loss in cell mass per day due to the oxidation of internal storage products of energy for cell maintenance, cell death and predation by organisms higher in the food chain. The maximum specific growth rate of the bacteria is related to the maximum specific substrate utilization rate $(\mathrm{k})$. When the substrate is being used at its maximum rate, the bacteria are also growing at the maximum rate. 
Figure 2 is a plot of the values of 1/SRT versus $U$ obtained from the ten experiments and this plotting gave a straight line. The slope of this straight line is the value of $\mathrm{Y}$ and the intercept is $\mathrm{K}_{\mathrm{d}}$. Therefore, from the Figure 2, the values of $\mathrm{Y}$ and $\mathrm{K}_{\mathrm{d}}$ can be recorded as about $0.055 \mathrm{~g} \mathrm{VSS} / \mathrm{g}$ BOD and about $0.12 \mathrm{~d}^{-1}$, respectively. Likewise, Figure 3 is a plot of the values of $1 / \mathrm{U}$ versus $1 / \mathrm{S}$ obtained from the experiments and one straight line was obtained from this figure. The slope of this straight line is $K_{s} / k$ and the intercept is $1 / k$. As a result, $\mathrm{K}_{\mathrm{s}}$ and $\mathrm{k}$ can be determined and they were about $340 \mathrm{mg} / \mathrm{l}$ and about $10 \mathrm{~d}^{-1}$, respectively. The variation of $\mathrm{Y}, \mathrm{K}_{\mathrm{d}}, \mathrm{K}_{\mathrm{s}}$ and $\mathrm{k}$ depending on the different concentration of soluble $\mathrm{BOD}_{5}$ of effluent, and MLSS in the IFAS process are presented in Table 2. The SRT and F/M ratio of the IFAS process were determined by using the Equations 1 and 2 according to [3] and [5]. The daily sludge disposal from the aeration tank was about 690 $\mathrm{mg} / \mathrm{l}$.

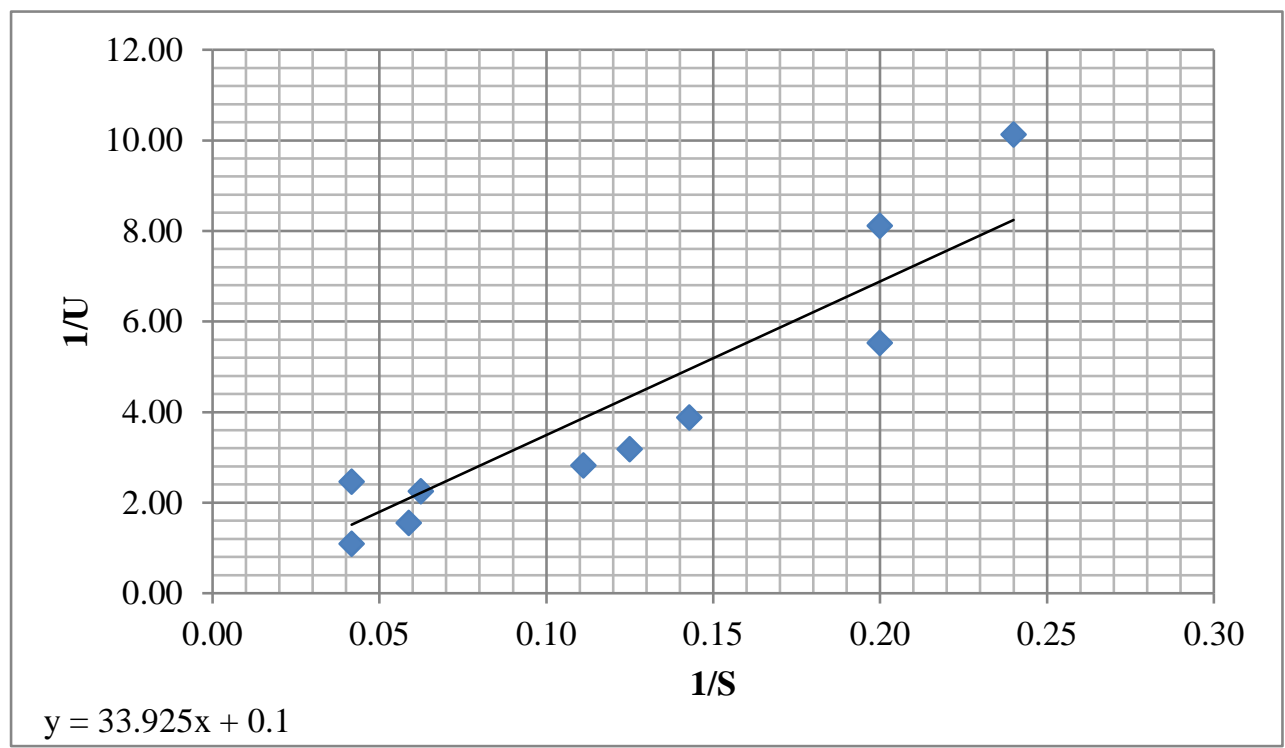

Figure 2. Determination of $\mathrm{Y}$ and $\mathrm{K}_{\mathrm{d}}$ through the relationship between SRT and F/M ratio

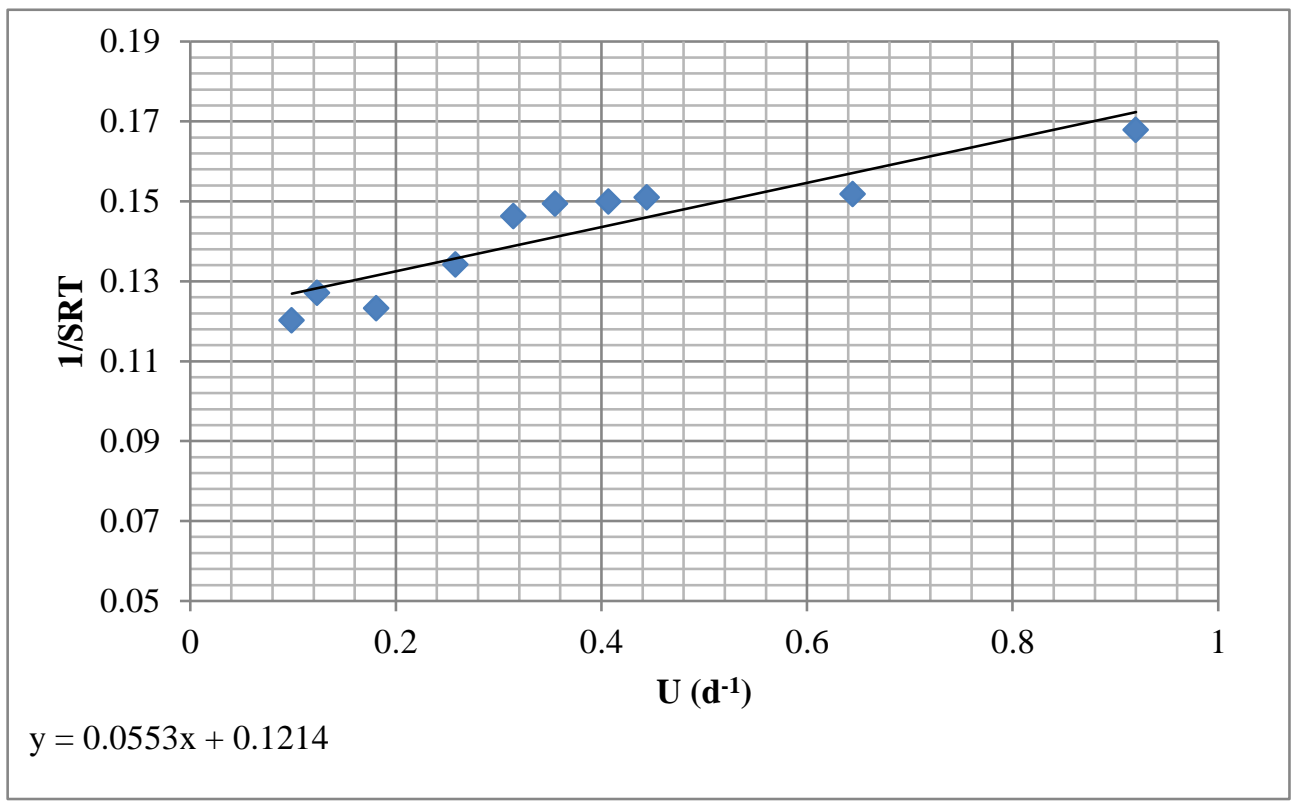

Figure 3. Determination of $\mathrm{K}_{\mathrm{s}}$ and $\mathrm{k}$ through the relationship between $\mathrm{F} / \mathrm{M}$ ratio and soluble $\mathrm{BOD}_{5}$ of effluent 
Table 2. Variation of $Y, K_{d}, K_{s}$ and $k$ in Different Experimental Conditions of IFAS Process

\begin{tabular}{ccccccccc}
\hline & \multicolumn{7}{c}{ Experimental Conditions of IFAS Process } \\
\cline { 2 - 9 } Experiments & $\begin{array}{c}\text { MLSS } \\
(\mathbf{m g} / \mathbf{l})\end{array}$ & $\begin{array}{c}\mathbf{U} \\
\left(\mathbf{d}^{-\mathbf{l}}\right)\end{array}$ & $\begin{array}{c}\mathbf{S} \\
(\mathbf{m g} / \mathbf{l})\end{array}$ & $\begin{array}{c}\text { SRT } \\
(\mathbf{d a y s})\end{array}$ & $\begin{array}{c}\mathbf{Y} \\
(\mathbf{g}-\mathbf{V S S} / \\
\mathbf{g - B O D})\end{array}$ & $\begin{array}{c}\mathbf{K}_{\mathbf{d}} \\
\left(\mathbf{d}^{\mathbf{1}}\right)\end{array}$ & $\begin{array}{c}\mathbf{K}_{\mathrm{s}} \\
(\mathbf{m g} / \mathbf{l})\end{array}$ & $\begin{array}{c}\mathbf{k} \\
\left(\mathbf{d}^{-\mathbf{l}}\right)\end{array}$ \\
\hline 1 & 5606 & 0.2 & 5.0 & 8.1 & - & - & - & - \\
2 & 4822 & 0.4 & 9.0 & 7.0 & - & - & - & - \\
3 & 4708 & 0.4 & 24.0 & 6.8 & 0.1 & 0.1 & 16 & 0.8 \\
4 & 4922 & 0.3 & 8.0 & 7.1 & 0.1 & 0.1 & 21 & 1.0 \\
5 & 5148 & 0.3 & 7.0 & 7.5 & 0.1 & 0.1 & 21 & 1.0 \\
6 & 4114 & 0.9 & 24.0 & 6.0 & 0.05 & 0.12 & 48 & 2.0 \\
7 & 5744 & 0.1 & 4.0 & 8.3 & 0.06 & 0.12 & 128 & 4.0 \\
8 & 4550 & 0.6 & 17.0 & 6.6 & 0.05 & 0.12 & 320 & 10.0 \\
9 & 4436 & 0.1 & 5.0 & 6.4 & 0.05 & 0.12 & 340 & 10.0 \\
10 & 4574 & 0.4 & 16.0 & 6.6 & 0.06 & 0.12 & 340 & 10.0 \\
\hline
\end{tabular}

SRT $($ days $)=[$ Lbs/day of suspended solids in aeration basin $] /[$ Lbs/day of Equation 1 suspended solids wasted from the system]

$$
\mathrm{U}=\mathrm{Q}_{\mathrm{in}}\left(\mathrm{S}_{0}-\mathrm{S}\right) /(\mathrm{V} \times \mathrm{MLVSS})
$$

Equation 2

Where, SRT = Sludge Retention Time (days), $U$ = ratio of the food to microorganisms (F/M ratio) $\left(\mathrm{d}^{-1}\right)$, $\mathrm{Q}_{\text {in }}=$ Influent flow rate $\left(\mathrm{m}^{3} /\right.$ day), $\mathrm{S}_{0}=$ Soluble $\mathrm{BOD}_{5}$ of influent $(\mathrm{mg} / \mathrm{l}), \mathrm{S}=$ Soluble BOD 5 of effluent $(\mathrm{mg} / \mathrm{l}), \mathrm{V}=$ Volume of aeration tank $\left(\mathrm{m}^{3}\right)$ and MLVSS $=$ Mixed Liquor Volatile Suspended Solids concentration (mg/l).

In this research, the anoxic process was provided for denitrification and to remove nitrogen compounds from wastewater. The determination of anoxic reactor's volume, required mixing rate and required mixed liquor recycle rate were considered in this anoxic process. The volume of anoxic reactor was bigger about 1.13 times than that of aerobic reactor. The mixing system was operated using motor with reduction gear and its rate of mixing was about 100 revolutions per minute (rpm). The volume of recycled mixed liquor to the anoxic reactor was estimated depending on the rate of denitrification.

Note: MLSS - Concentration of Mixed Liquor Suspended Solids (mg/l), U Food to Microorganisms ratio $\left(\mathrm{d}^{-1}\right), \mathrm{S}-$ Soluble $\mathrm{BOD}_{5}$ of treated effluent $(\mathrm{mg} / \mathrm{l}), \mathrm{SRT}-$ Sludge Retention Time (days), Y - Yield of biomass growth (g VSS/g BOD), $\mathrm{K}_{\mathrm{d}}$ Endogenous decay coefficient $\left(\mathrm{d}^{-1}\right), \mathrm{K}_{\mathrm{s}}$ - Substrate concentration at one-half the maximum growth rate $(\mathrm{mg} / \mathrm{l})$ and $\mathrm{k}$ - Maximum rate of substrate utilization per unit mass of microorganisms $\left(\mathrm{d}^{-1}\right)$

To achieve the denitrification process, the maintenance of the amount of aerobic microbes under non aerated condition in the anoxic reactor is important factor because these microbes consume the oxygen from the nitrogen compounds like $\mathrm{NO}_{3}-\mathrm{N}$ to create free nitrogen gas that will escape to the atmosphere. The relationship between the specific rate of denitrification (SRDN) and the food to microorganism ratio (F/M ratio) in the anoxic zone was determined by plotting these two considerations in the linear trendline as shown in Figure 4. The values of SRDN, F/M ratio, MLSS concentration in the anoxic zone and $\mathrm{NO}_{3}-\mathrm{N}$ concentration before and after anoxic process are tabulated in Table 3 . 


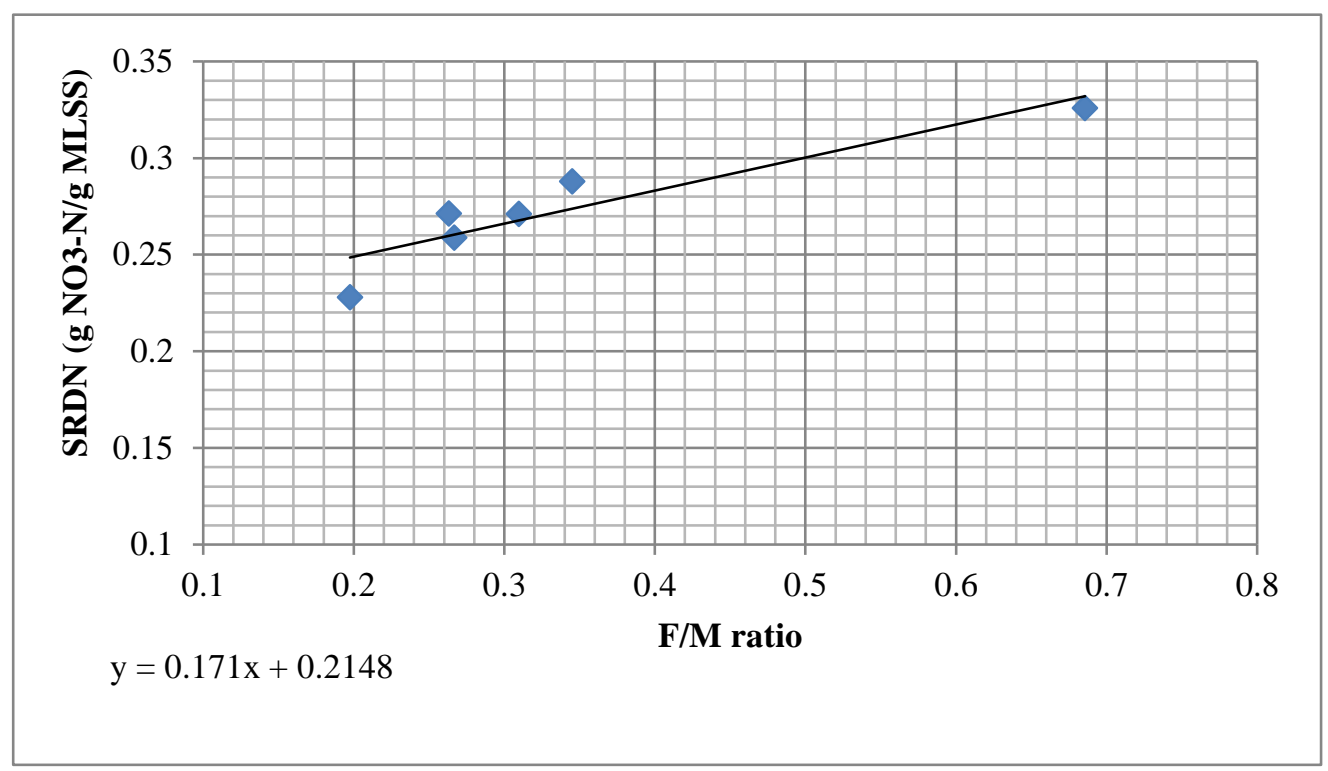

Figure 4. Relationship between SRDN and F/M ratio in the anoxic zone

Table 3. Experimental Conditions of Anoxic Process

\begin{tabular}{ccccc}
\hline \multirow{2}{*}{ Experiments } & \multicolumn{4}{c}{ Experimental conditions of anoxic process } \\
\cline { 2 - 5 } & $\begin{array}{c}\text { MLSS } \\
(\mathbf{m g} / \mathbf{l})\end{array}$ & $\begin{array}{c}\text { F/M ratio } \\
\left(\mathbf{d}^{-\mathbf{l}}\right)\end{array}$ & $\begin{array}{c}\text { SRDN } \\
\text { (g NO }_{3}-\mathbf{N} / \mathbf{g} \text { MLSS -day) }\end{array}$ & $\begin{array}{c}\text { Amount of } \mathbf{~ O}_{3} \text {-N } \\
\text { removal (mg/l) }\end{array}$ \\
\hline 5 & & & 0.23 & 900 \\
6 & 3950 & 0.2 & 0.26 & 1260 \\
7 & 4872 & 0.3 & 0.27 & 1050 \\
8 & 3874 & 0.3 & 0.29 & 1034 \\
9 & 3592 & 0.3 & 0.27 & 1237 \\
10 & 4562 & 0.3 & 0.33 & 1140 \\
\hline
\end{tabular}

The specific rate of denitrification depends mainly on the organic loading rate, the concentration of MLSS and the nature of the wastewater. According to the Figure 4, the relationship between SRDN and F/M ratio in the anoxic zone can be recorded as shown in the Equation 3. By using this equation, the mass of nitrate removed from the wastewater in the anoxic tank can be calculated from the MLSS concentration and the F/M ratio in the anoxic zone. The Table 5 and Figure 6 illustrate the results of the $5^{\text {th }}, 6^{\text {th }}, 7^{\text {th }}, 8^{\text {th }}, 9^{\text {th }}$ and $10^{\text {th }}$ experiments that can reduce successfully the concentration of $\mathrm{NO}_{3}-\mathrm{N}$ in the anoxic zone. Depending on the results described in Table 5, the maximum amount of $\mathrm{NO}_{3}-\mathrm{N}$ can be reduced from the wastewater in the anoxic reactor at the $9^{\text {th }}$ experiment.

$$
\mathrm{SRDN}=0.171 \mathrm{~F} / \mathrm{M} \text { ratio }+0.2148
$$

Equation 3

Where, SRDN = specific rate of denitrification in the anoxic zone $\left(\mathrm{g} \mathrm{NO}_{3}-\mathrm{N} / \mathrm{g}\right.$ MLSS-day) and $\mathrm{F} / \mathrm{M}$ ratio $=$ food to microorganism ratio in the anoxic zone $\left(\mathrm{d}^{-1}\right)$

\section{Analytical Process of Pollution Parameters}

The influent wastewater sample and treated sample collected from every treatment step such as aeration, anoxic and sedimentation was analysed in the Environmental Engineering Laboratory of Yangon Technological University. The concentrations of biochemical oxygen demand (BOD), chemical oxygen demand (COD), total suspended solids (TSS) 
were measured using the Standard Methods [1]. The concentration of ammonia nitrogen $\left(\mathrm{NH}_{3}-\mathrm{N}\right)$ and nitrate nitrogen $\left(\mathrm{NO}_{3}-\mathrm{N}\right)$ were determined by using photometer (YSI 9300). The $\mathrm{pH}$ and temperature of wastewater sample were examined using the $\mathrm{pH}$ meter (TRANS Instruments) and the thermometer (Brannan England BS 593).

\section{Removal of Nitrogen Compounds from Municipal Wastewater}

Depending on the outcomes of the experiments, the nitrification process of aeration system can reduce successfully the ammonia nitrogen concentration at all operational conditions. From this study, it was found that the reduction of ammonia nitrogen and nitrate nitrogen depended on the concentration of MLVSS in the aeration and anoxic tanks as well as anoxic residence time. Since the anoxic residence time for $1^{\text {st }}$ and $2^{\text {nd }}$ experiments were about only 24 hours, both ammonia nitrogen and nitrate nitrogen cannot be removed well during anoxic process. In $3^{\text {rd }}$ and $4^{\text {th }}$ experiments, the anoxic residence time were increased to about 48 hours. However, the removal efficiency did not improve significantly. These four experiments cannot remove well nitrogen compounds by means of aeration and anoxic processes. Therefore, the anoxic residence time was raised to 36 hours for $5^{\text {th }}$ and $6^{\text {th }}$ experiments. In these experiments, it was found that the removal efficiency of ammonia nitrogen and nitrate nitrogen were slightly increased. The amount of returned sludge from sedimentation tank to aeration tank did not change for above six experiments. In order to determine the optimum operational condition and treatment efficiency of this treatment system, the ratio of returned sludge flow rate and influent flow rate from sedimentation tank to aeration tank and anoxic tank were changed as 0.28 and 0.14 , respectively for $7^{\text {th }}$ and $8^{\text {th }}$ experiments with 48 hours of anoxic residence time. During these experiments, the removal efficiency of ammonia nitrogen was around $98 \%$ and $96 \%$, and nitrate nitrogen was around $78 \%$ and $89 \%$, respectively. Then, the ratio of $\mathrm{Q}_{\mathrm{r}}$ and $\mathrm{Q}_{\text {in }}$ were changed as 0.14 and 0.28 to aeration tank and anoxic tank from sedimentation tank for $9^{\text {th }}$ and $10^{\text {th }}$ experiments with the same anoxic residence time of 48 hours. During these experiments, the removal efficiency of both nitrogen compounds were around $94 \%$ and $92 \%$ for ammonia nitrogen and around $98 \%$ and $97 \%$ for nitrate nitrogen.

According to the results obtained from the ten experiments using lab-scaled IFAS process and anoxic process, the changes of ammonia nitrogen concentration and nitrate nitrogen concentration in the influent and effluent with different operational conditions, can be tabulated as shown in Table 4 and Table 5, respectively.

Table 4. Different Concentration of Ammonia Nitrogen in Influent and Effluent of Lab-scaled Treatment System

\begin{tabular}{ccccc}
\hline Experiments & $\begin{array}{c}\text { Operational } \\
\text { Condition }\end{array}$ & $\begin{array}{c}\text { Influent } \\
(\mathbf{m g} / \mathbf{l})\end{array}$ & $\begin{array}{c}\text { Effluent } \\
(\mathbf{m g} / \mathbf{l})\end{array}$ & $\begin{array}{c}\text { Removal Efficiency } \\
(\mathbf{\%})\end{array}$ \\
\hline 1 & 1 & 120 & 30 & 75.0 \\
2 & 1 & 90 & 30 & 66.7 \\
3 & 2 & 80 & 30 & 62.5 \\
4 & 2 & 60 & 20 & 66.7 \\
5 & 3 & 3400 & 300 & 91.2 \\
6 & 3 & 1500 & 100 & 93.3 \\
7 & 4 & 1700 & 30 & 98.2 \\
8 & 4 & 700 & 30 & 95.7 \\
9 & 5 & 500 & 30 & 94.0 \\
10 & 5 & 218 & 18 & 91.7 \\
\hline
\end{tabular}


Table 5. Different Concentration of Nitrate Nitrogen in Influent and Effluent of Labscaled Treatment System

\begin{tabular}{ccccc}
\hline Experiments & $\begin{array}{c}\text { Operational } \\
\text { Condition }\end{array}$ & $\begin{array}{c}\text { Influent } \\
(\mathbf{m g} / \mathbf{l})\end{array}$ & $\begin{array}{c}\text { Effluent } \\
(\mathbf{m g} / \mathbf{l})\end{array}$ & $\begin{array}{c}\text { Removal Efficiency } \\
(\mathbf{\%})\end{array}$ \\
\hline 1 & 1 & 35 & 41 & - \\
2 & 1 & 61 & 53 & 13.1 \\
3 & 2 & 236 & 51 & 78.4 \\
4 & 2 & 220 & 79.6 & 63.8 \\
5 & 3 & 2700 & 950 & 64.8 \\
6 & 3 & 2865 & 640 & 77.7 \\
7 & 4 & 1880 & 415 & 77.9 \\
8 & 4 & 2510 & 285 & 88.6 \\
9 & 5 & 2600 & 61 & 97.7 \\
10 & 5 & 2910 & 80 & 97.3 \\
\hline
\end{tabular}

According to the results from these experiments, the concentration of nitrate nitrogen in municipal wastewater cannot be reduced well due to inadequate anoxic residence time in the anoxic tank although the ammonia nitrogen concentration can be reduced well by aeration tank with fabious media. In order to get the optimum removal efficiency for both ammonia nitrogen and nitrate nitrogen concentration, the adjustment of MLSS concentration by recycling of returned sludge and the anoxic residence time by varying the duration of mixing process in the anoxic zone was performed. The optimum removal efficiency was obtained at the $9^{\text {th }}$ experiment in which the removal efficiency of ammonia nitrogen was around $94 \%$ and nitrate nitrogen was around $98 \%$, respectively, with 48 hours of anoxic residence time as well as about 0.14 and 0.28 of $\mathrm{Q}_{\mathrm{r}} / \mathrm{Q}_{\text {in }}$ ratio for aeration tank and anoxic tank. The different concentrations of ammonia nitrogen and nitrate nitrogen in the influent and effluent and corresponding removal efficiency of this lab-scaled municipal wastewater treatment system are illustrated in Figure 5 and Figure 6.

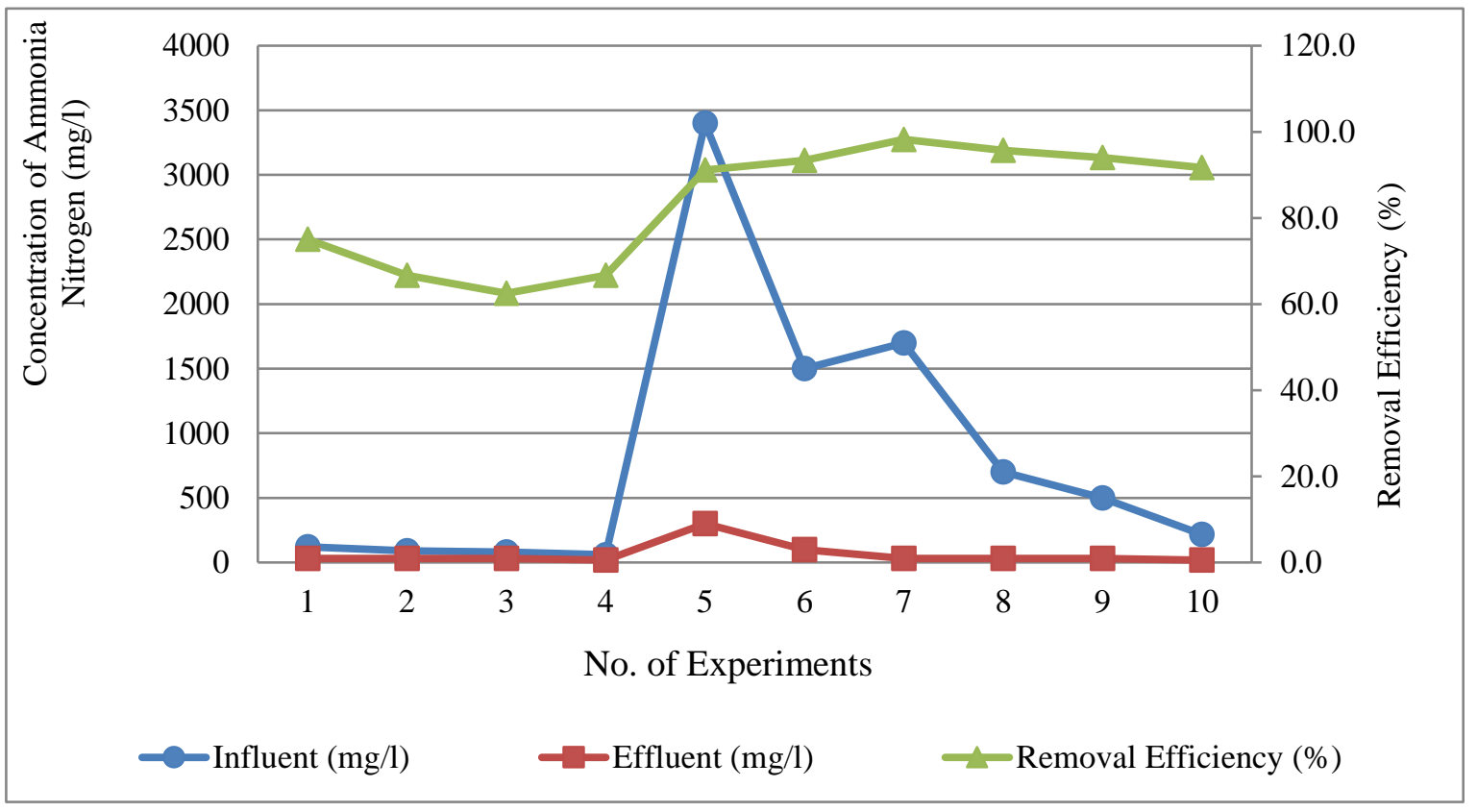

Figure 5. Comparison of ammonia nitrogen concentration between influent and effluent of lab-scaled treatment system with related removal efficiency 


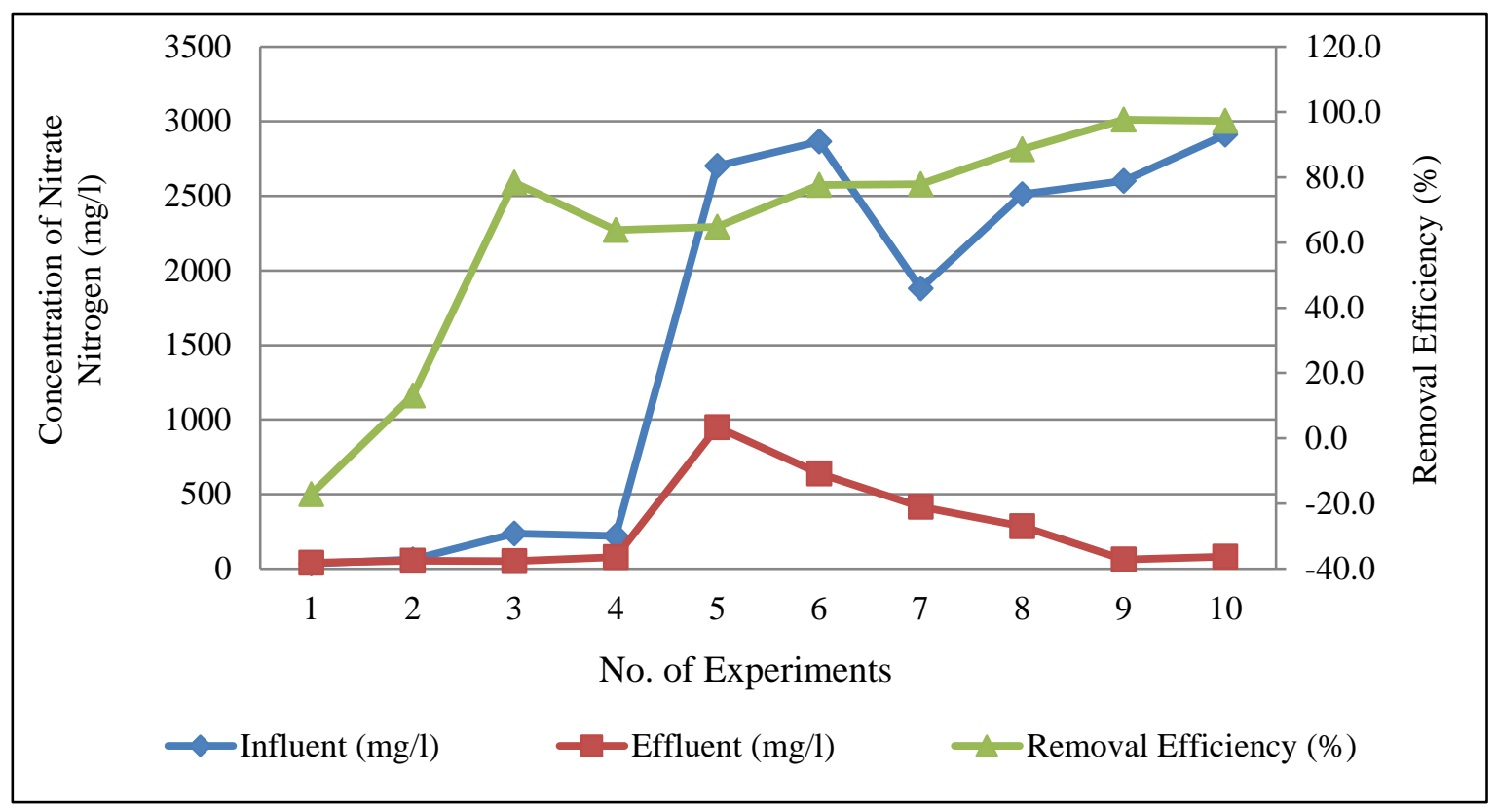

Figure 6. Comparison of nitrate nitrogen concentration between influent and effluent of lab-scaled treatment system with related removal efficiency

\section{Conclusions}

In IFAS process, the Sludge Retention Time (SRT) varied between 6.0 days and 8.3 days and the Food to Microorganisms ratio (F/M) changed between $0.1 \mathrm{~d}^{-1}$ and $0.9 \mathrm{~d}^{-1}$ during the experiments. In anoxic process, the effluent from the aerobic reactor was treated with different anoxic residence times that are 24 hours, 48 hours and 36 hours with or without recycling the Returned Activated Sludge (RAS) from the sedimentation tank to the anoxic tank. From this study, it can be realized that the enough population of microbes to consume oxygen from nitrate nitrogen in the wastewater should be maintained by adding RAS that was around $10 \%$ of the volume of anoxic zone. Moreover, it can be seen that about 48 hours of ART should be provided in order to get the adequate reaction time between microbes and nitrogen compounds in the wastewater. Finally, it can be concluded that the maximum treatment efficiency of anoxic process was obtained in operational condition no. 5 after adding the two-third of the volume of RAS to the anoxic tank with 48 hours of anoxic residence time. The optimum treatment efficiency was obtained in the $9^{\text {th }}$ experiment with about $94.0 \%$ of $\mathrm{NH}_{3}-\mathrm{N}$ and $97.7 \%$ of $\mathrm{NO}_{3}-\mathrm{N}$, respectively. In this $9^{\text {th }}$ experiment, the value of $\mathrm{Y}, \mathrm{K}_{\mathrm{d}}, \mathrm{K}_{\mathrm{s}}$ and $\mathrm{k}$ were about $0.05 \mathrm{~g}-\mathrm{VSS} / \mathrm{g}-\mathrm{BOD}, 0.12 \mathrm{~d}^{-1}, 340 \mathrm{mg} / \mathrm{l}$ and $10 \mathrm{~d}^{-1}$, respectively in the IFAS process while the SRDN was about $0.27 \mathrm{~g} \mathrm{NO}_{3}-\mathrm{N} / \mathrm{g}$ MLSS per day in the anoxic process. The ammonia nitrogen and nitrate nitrogen concentration can be reduced from $500 \mathrm{mg} / \mathrm{l}$ to $30 \mathrm{mg} / \mathrm{l}$ and from $2600 \mathrm{mg} / \mathrm{l}$ to $61 \mathrm{mg} / \mathrm{l} \mathrm{in}$ this experiment, respectively. This study can prove that the concentration of ammonia nitrogen and nitrate nitrogen in the municipal wastewater that has very high concentration of BOD and ammonia nitrogen by using fabious media in the IFAS process as well as by arranging anoxic tank between aeration tank and sedimentation tank. The treatment system mentioned in this paper can be applicable for nutrient removal process of domestic wastewater that has similar characteristics with the sampled wastewater used in this study.

\section{Acknowledgement}

The author firstly would like to thank Professor Dr. Nyan Myint Kyaw, Head of Civil Engineering Department, YTU, for his permission to do this research and the acceptance to 
publish this paper in the AEJ journal. Moreover, the author would like to express her sincere gratitude to her supervisor, Dr. Theingi Ye Myint, Visiting Lecturer of Civil Engineering Department, YTU and her co-supervisor, Dr. Cho Cho Thin Kyi, Associate Professor of Civil Engineering Department, YTU for their kind help and valuable suggestions for this research. Furthermore, the author is very grateful for Daw Khin Aye Myint, Executive Engineer, Engineering Department (Water and Sanitation) of Yangon City Development Committee (YCDC) for her kind permission to collect wastewater sample for this research. Additionally, the author would specially thank Japan International Cooperation Agency (JICA) due to its financial support to buy the chemical reagents used for determination of ammonia nitrogen and nitrate nitrogen concentration in the wastewater. Finally, the author would like to thank Hitachi Zosen Corporation for their supporting of fabious media for IFAS process in this research.

\section{References}

[1] American Public Health Association, American Water Works Association, and Water Environment Federation, "Standard Method for the Examination of Water and Wastewater," 2018 [Online]. Available: https://www.standardmethods.org/tocpart [Accessed: January 2018]

[2] BRENTWOOD, "Integrated Fixed Film/ Activated Sludge (IFAS) Technology," 2009 [Online]. Available: http://archive.sswm.info/category/implementationtools/wastewater-treatment/hardware/semi-centralised-wastewater-treatments-4 [Accessed: December 2016]

[3] Kentucky Department for Environmental Protection, "Sludge Age vs. Solids Retention and Mean Cell Residence Time," 2012 [Online]. Available: https://kyocp.wordpress.com/2012/05/17/sludge-age-vs-solids-retention-and-meancell-residence-time/ [Accessed: December 2016]

[4] R. Sedlak, Phosphorus and Nitrogen Removal from Municipal Wastewater, Principles and Practice, $2^{\text {nd }}$ Edition, The Soap and Detergent Association, New York, United States, 1991.

[5] S.R. Qasim, Wastewater Treatment Plants, Planning, Design, and Operation, CBS International Edition, CBS College Publishing, New York, United States, 1985.

[6] T.L. Johnson, A.R. Shaw, H. Phillips, N. Choi, T. Lauro, R. Butler, and L. Radko, “A pilot-scale comparison of IFAS and MBBR to achieve very low total nitrogen concentrations," Journal of Water Practice, Vol. 1, No. 5, pp. 1-14, 2007.

[7] Mecalf \& Eddy, G. Tchobanoglous, F.L. Burton, and H.D. Stensel, Wastewater Engineering Treatment and Reuse, $4^{\text {th }}$ Edition, McGraw-Hill Book Co., New York, United States, 2003.

[8] M. Farrokhi, D. Ashrafi, E. Roohbakhsh, and A. Yoonesi, "Hospital wastewater treatment by integrated fixed film activated sludge, using rice husk as fixed media," Journal of Advances in Life Sciences, Vol. 4, No. 3, pp. 178-183, 2014.

[9] T. Sriwiriyarat, and C.W. Randall, "Performance of IFAS wastewater treatment processes for biological phosphorus removal," Journal of Water Research, Vol. 39, No. 16, pp. 3873-3884, 2005. 